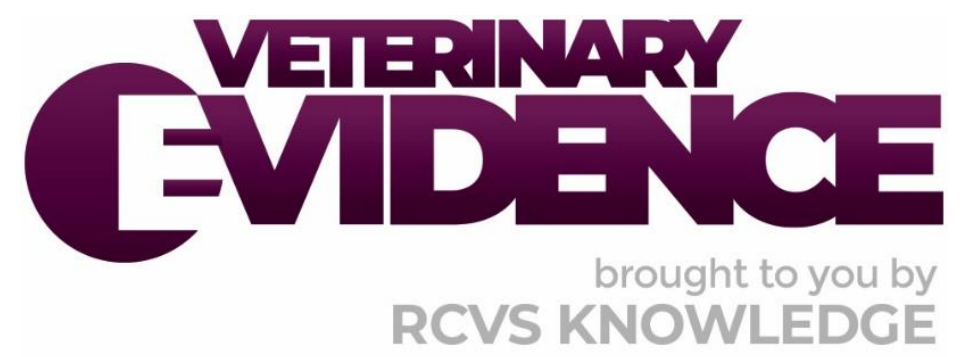

\title{
Healing of equine heel bulb lacerations: Evidence behind casting compared to bandaging alone
}

A Knowledge Summary by

Jonathan Ruiz BVetMed Sci (Hons), BVM, BVS, MRCVS ${ }^{1}$

Julia Dubuc DMV, DÉS, DACVS-LA, M.SC, MRCVS ${ }^{1 *}$

${ }^{1}$ University of Nottingham, Sutton Bonnington Campus, Sutton Bonnington, Leicestershire, LE12 5RD

*Corresponding Author (julia.dubuc@nottingham.ac.uk)

ISSN: 2396-9776

Published: 03 Apr 2020

in: Vol 5, Issue 2

DOI: $\underline{10.18849 / V E . V 5 I 2.255}$

Reviewed by: Josh Slater (PhD, Dip ECEIM) and Debbie Archer (BVMS, PhD CertES(Soft Tissue), DipECVS, FRCVS, FHEA)

Next Review Date: 07 Dec 2020 


\section{KNOWLEDGE SUMMARY}

\section{PICO question}

In horses with heel bulb lacerations, does casting the distal limb compared to bandaging result in increased speed of healing and functional outcome?

\section{Clinical bottom line}

\section{Category of research question}

\section{Treatment}

\section{The number and type of study designs reviewed}

A single retrospective study was found to be relevant to the topic along with one case report and two case series, including one tutorial article

\section{Strength of evidence}

The majority of the current recommendations come from expert opinions, making the level of evidence low

\section{Outcomes reported}

There are currently insufficient data to compare the effect of foot/slipper casts versus bandaging alone on the rate of healing of equine heel bulb lacerations

\section{Conclusion}

Based on the information from these three publications, it is not possible to recommend the use of a foot cast over a bandage alone at this time

\section{$\underline{\text { How to apply this evidence in practice }}$}

The application of evidence into practice should take into account multiple factors, not limited to: individual clinical expertise, patient's circumstances and owners' values, country, location or clinic where you work, the individual case in front of you, the availability of therapies and resources.

Knowledge Summaries are a resource to help reinforce or inform decision making. They do not override the responsibility or judgement of the practitioner to do what is best for the animal in their care.

\section{Clinical Scenario}

You are called out to a 10-year-old Cob gelding which has sustained a heel bulb laceration after jumping into the neighbouring field over a fence covered in barbed wire. The laceration is located on the lateral heel bulb of the right hindlimb and is $5 \mathrm{~cm}$ long. It extends from the lateral hoof wall, across the coronet and reaches $2 \mathrm{~cm}$ proximal to the coronet in a lateroproximal to mediodistal direction. The horse is consistently lames at the trot in a straight line ( $3 / 5 \mathrm{AAEP})$ on that limb and the laceration appears very contaminated with soil. 


\section{The evidence}

The literature comprises several non-peer reviewed publications, such as CPD material and tutorial articles. Only one retrospective case study, including a large number of horses treated with bandaging and/or casting, was found. Based on the publications currently available, there is sparse evidence that casting is superior to bandaging for healing of heel bulb lacerations in the horse and the quality of the evidence is considered low.

\section{Summary of the evidence}

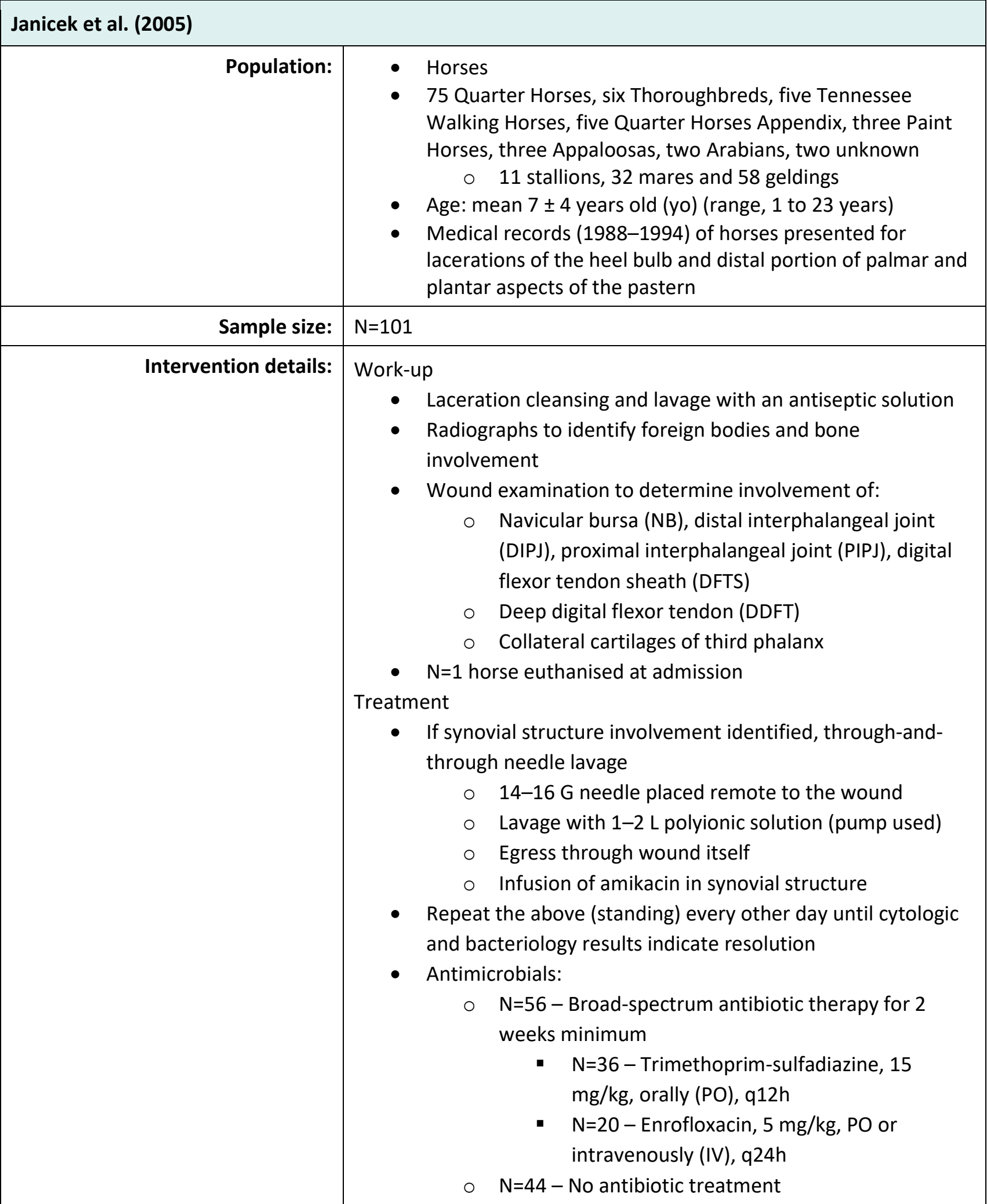




\begin{tabular}{|c|c|}
\hline & 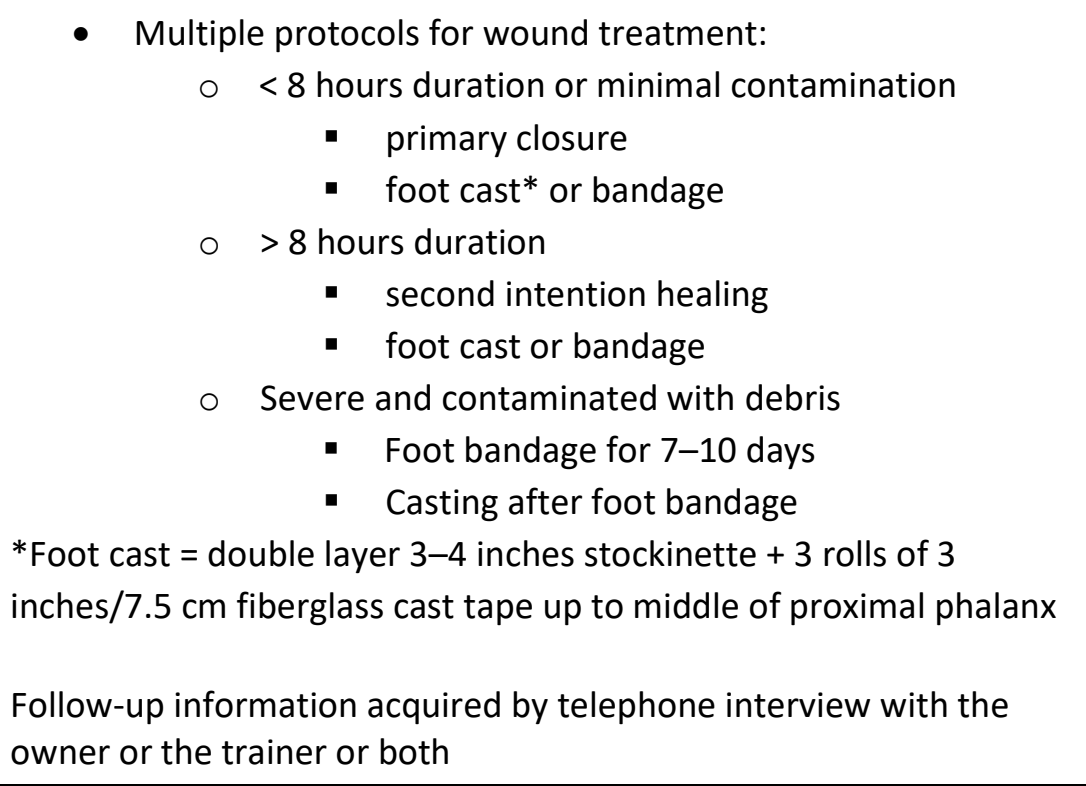 \\
\hline Study design: & Retrospective case series \\
\hline Outcome studied: & $\begin{array}{l}\text { - Successful outcome: sound horse able to be used at a level of } \\
\text { performance that equaled or exceeded the level achieved } \\
\text { before surgery } \\
\circ \text { foot cast versus foot bandage } \\
\circ \text { synovial involvement versus no synovial involvement }\end{array}$ \\
\hline $\begin{array}{l}\text { Main findings: } \\
\text { (relevant to PICO question): }\end{array}$ & 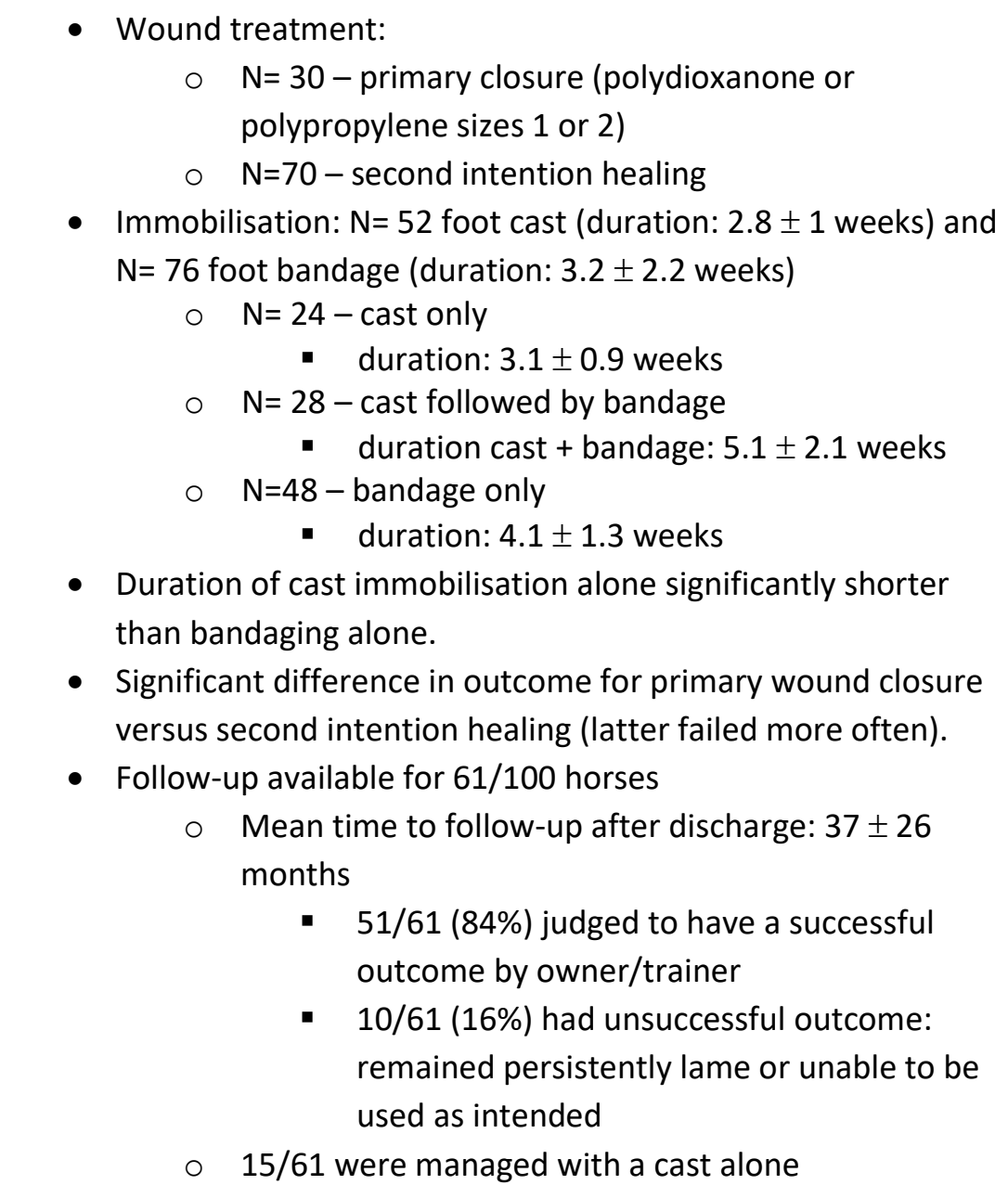 \\
\hline
\end{tabular}




\begin{tabular}{|c|c|}
\hline & $\begin{array}{l}\text { - 2/15 (13.3\%) had cast complications } \\
\text { (pressure necrosis of skin) } \\
\text { - } 11 / 61 \text { (18\%) hoof wall defect developed } \\
\text { after injury }\end{array}$ \\
\hline Limitations: & $\begin{array}{l}\text { - No control group and no random allocation of wound } \\
\text { - Choitment (cast vs bandage) } \\
\text { - Very little detail on complications for bandaging group and } \\
\text { bandaging + casting together } \\
\text { - Unclear how many horses: } \\
\text { o with second intention healing or primary wound } \\
\text { closure were treated with a foot cast alone or } \\
\text { bandage alone and if this is a confounding factor } \\
\text { with synovial involvement were treated with a foot } \\
\text { cast versus a bandage alone and which one would } \\
\text { lead to faster healing in such cases } \\
\text { - Limited outcome information and very subjective as assessed } \\
\text { by trainer/owner }\end{array}$ \\
\hline
\end{tabular}

\begin{tabular}{|c|c|}
\hline \multicolumn{2}{|l|}{ Booth \& Knottenbelt (1999) } \\
\hline Population: & Horses (one Arab, one Irish draft and two unknown) \\
\hline Sample size: & $N=4$ \\
\hline Intervention details: & $\begin{array}{l}\text { - Location of wounds: } \\
\quad \text { Coronet }(\mathrm{N}=1) \\
\circ \text { Heel bulb laceration ( } \mathrm{N}=2) \\
\circ \quad \text { Laterodistal aspect one forelimb }(\mathrm{N}=1) \\
\text { - Surgical debridement in all cases } \\
\text { - Wounds sutured ( } \mathrm{N}=2) \\
\text { - Bandage daily for } 5 \text { days ( } \mathrm{N}=1 \text { horse, prior to cast application) } \\
\text { - Foot cast applied in all cases } \\
\circ 4 \text { weeks duration }(\mathrm{N}=3) \\
\circ 8 \text { weeks duration }(\mathrm{N}=1)\end{array}$ \\
\hline Study design: & Tutorial article with small case series as examples \\
\hline Outcome studied: & $\begin{array}{l}\text { - Mainly wound healing: } \\
\quad \text { soundness } \\
\circ \text { hoof wall defect }\end{array}$ \\
\hline $\begin{array}{l}\text { Main findings: } \\
\text { (relevant to PICO question): }\end{array}$ & $\begin{array}{l}\text { - All wounds healed } \\
\text { - } \mathrm{N}=1 \text { : cast sore (cast on for } 4 \text { weeks) } \\
\quad 0 \quad \text { of no apparent clinical significance } \\
\text { - } \mathrm{N}=1 \text { : hoof wall defect (noticed at } 4 \text { years follow-up) }\end{array}$ \\
\hline Limitations: & $\begin{array}{l}\text { - Very small case series with limited details for each } \\
\text { - No bandage group to compare }\end{array}$ \\
\hline
\end{tabular}




\begin{tabular}{|l|c|}
\hline - Unclear why one cast was left in place for 8 weeks \\
$\circ$ heel bulb laceration case \\
- Unclear how many cast were placed under general (versus \\
regional anaesthesia) and if difference in cast complications \\
- Affected limb not always identified \\
$\circ \quad$ unclear if difference in healing between fore and \\
hind limbs \\
- Very limited long-term follow-up (available for one case only) \\
\hline
\end{tabular}

\begin{tabular}{|c|c|}
\hline \multicolumn{2}{|l|}{ Ketzner et al. (2009) } \\
\hline Population: & $\begin{array}{l}\text { Horses } \\
\text { - } 27 \text { Quarter Horses, six Paints, five mixed breeds, three } \\
\text { Warmbloods, two Arabians, two Thoroughbreds, one } \\
\text { Appaloosa, one Saddlebred, one Belgian, one unknown breed } \\
\text { - Three stallions, } 26 \text { mares and } 20 \text { geldings } \\
\text { - Age: mean } 7.2 \pm 5.5 \text { years old (yo) (range, } 1 \text { to } 25 \text { years) } \\
\text { Medical records (1995-2007) of horses with wounds of the pastern } \\
\text { and foot region, presented to three university equine hospitals. }\end{array}$ \\
\hline Sample size: & $\mathrm{N}=49$ horses with 50 wounds (cases) \\
\hline Intervention details: & 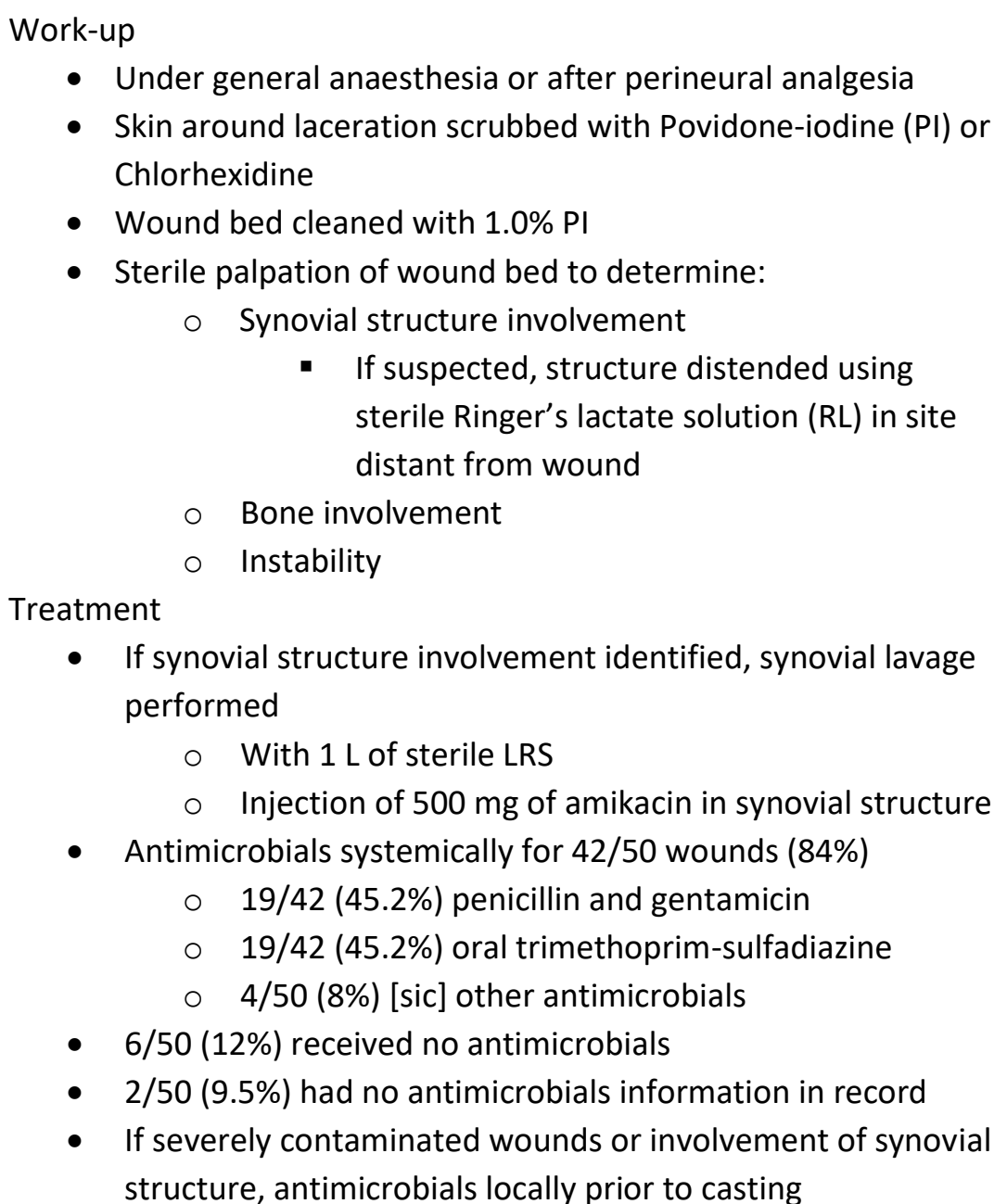 \\
\hline
\end{tabular}




\begin{tabular}{|c|c|}
\hline & 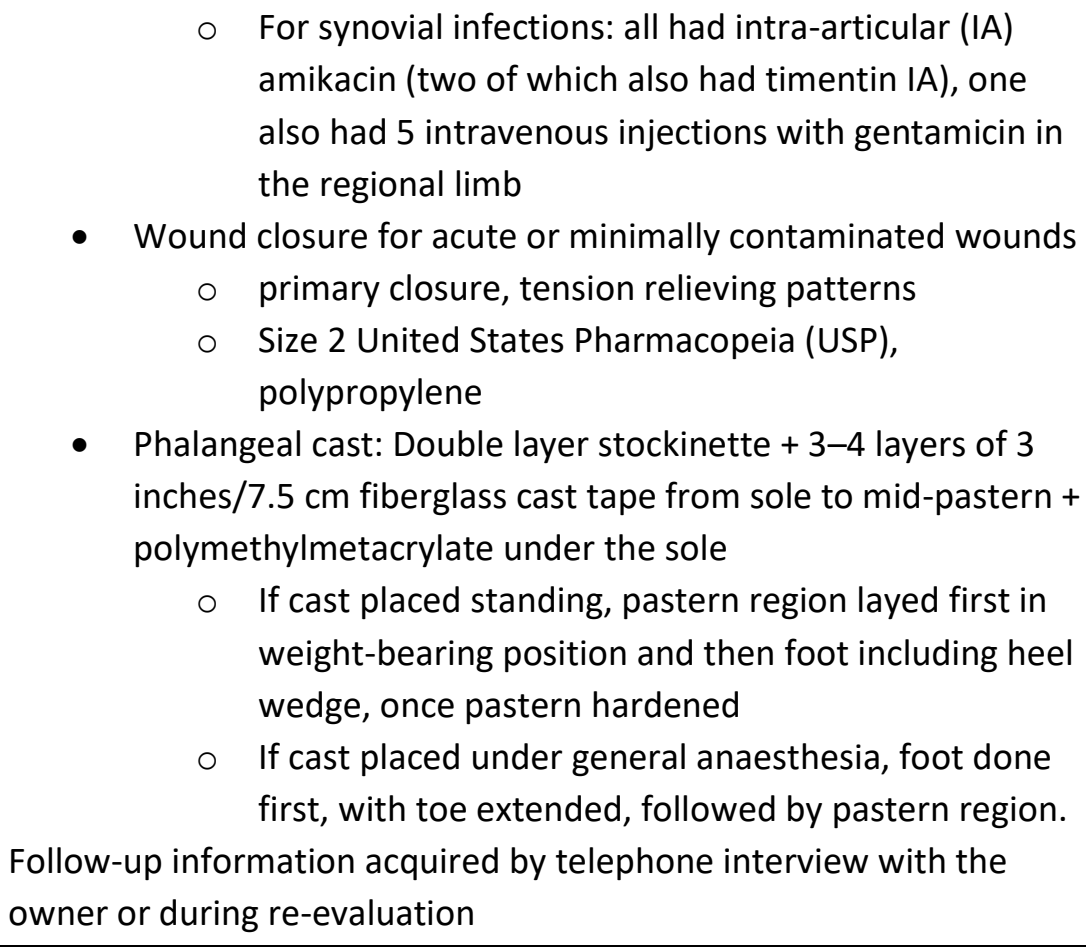 \\
\hline Study design: & Retrospective case series \\
\hline Outcome studied: & $\begin{array}{l}\text { - Soundness: sound if no lameness and back to previous level } \\
\text { - Wound appearance } \\
\quad \text { Excellent (no scaring), very good (minimal scaring), } \\
\text { excessive scaring } \\
\text { - Complications }\end{array}$ \\
\hline $\begin{array}{l}\text { Main findings: } \\
\text { (relevant to PICO question): }\end{array}$ & 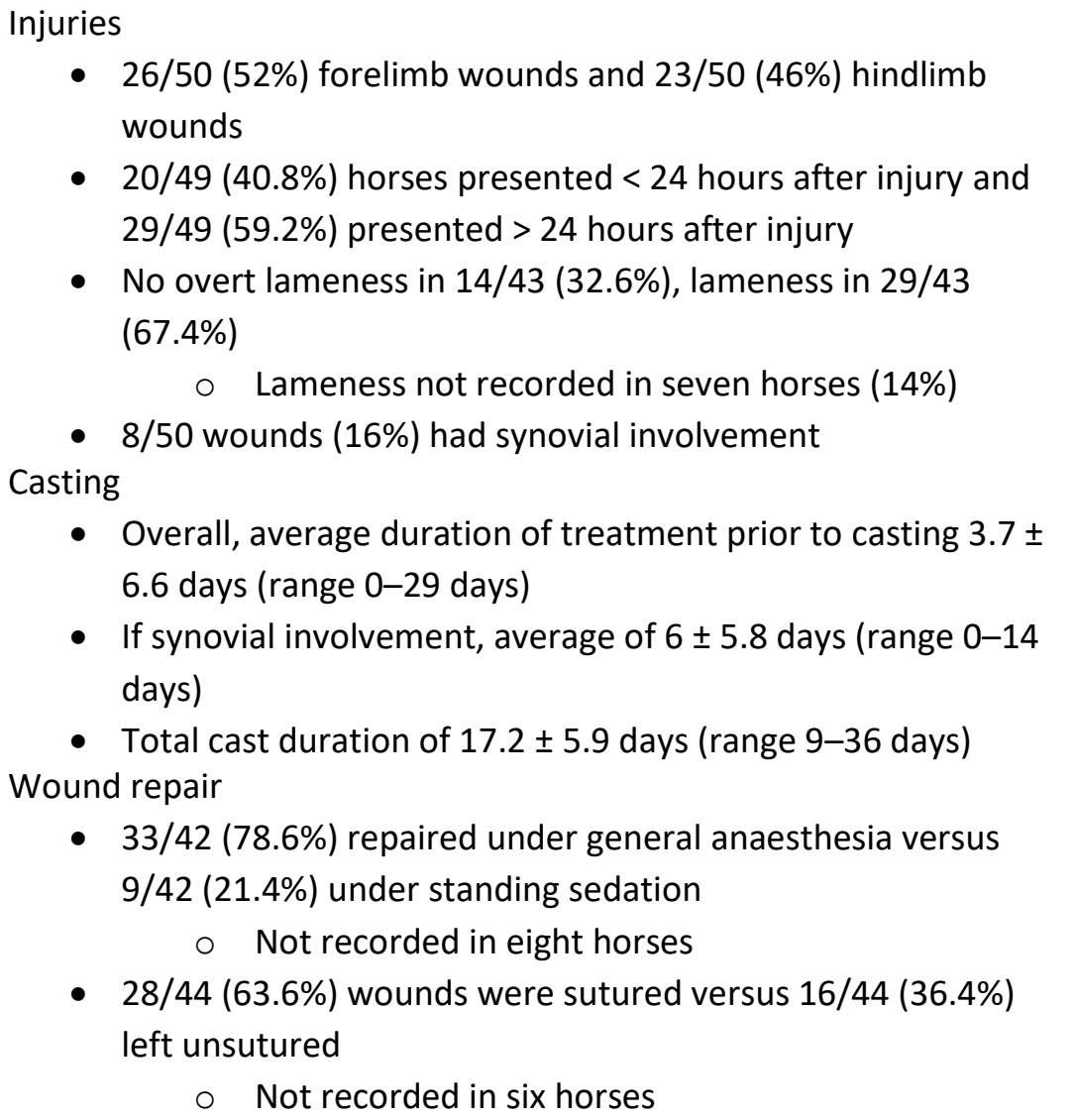 \\
\hline
\end{tabular}




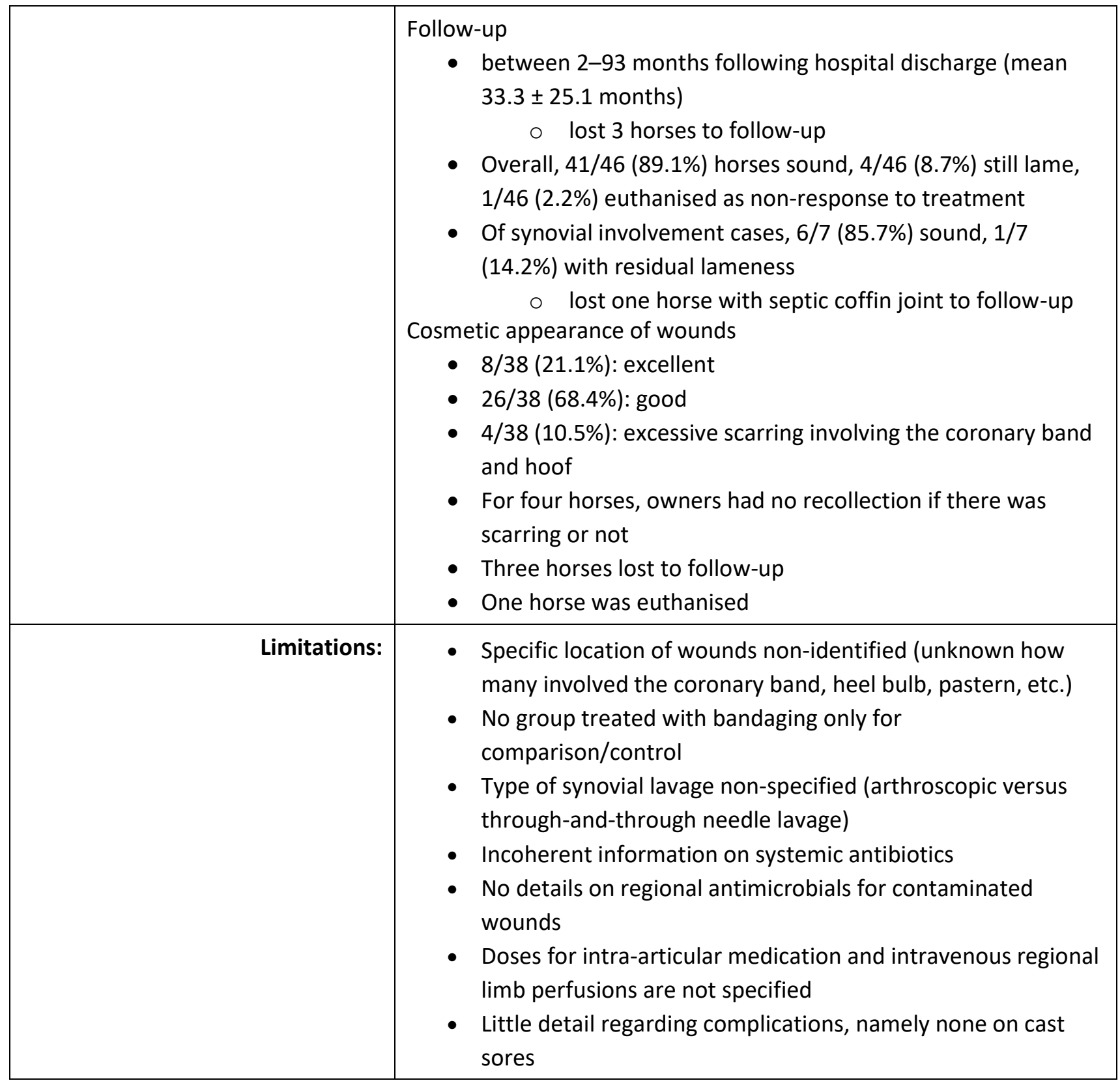

\begin{tabular}{|c|c|}
\hline Milner (2008) & \\
\hline Population: & 13-year-old Cob gelding \\
\hline Sample size: & $\mathrm{N}=1$ \\
\hline Intervention details: & $\begin{array}{l}\text { - Crescent shape full-thickness laceration of medial heel bulb in } \\
\text { left forelimb } \\
\circ \text { No synovial involvement identified } \\
\circ \text { Exposure of proximomedial edge of medial ungular } \\
\text { cartilage } \\
\text { - Wound lavage and foot bandage changed daily until day } 4 \\
\text { - On day 4, hydrosurgical (Versajet }{ }^{\mathrm{TM}} \text { ) and sharp debridement } \\
\text { under general anaesthesia } \\
\circ 1.25 \text { mm cerclage wires (x2) used to retain the }\end{array}$ \\
\hline
\end{tabular}




\begin{tabular}{|c|c|}
\hline & $\begin{array}{l}\text { medial hoof wall in place } \\
\circ \text { Foot cast (to mid-proximal pastern) for the following } \\
14 \text { days } \\
\text { - After cast removal, shoe with central support and } \\
\text { polyurethane infiller in the sole for } 4 \text { weeks } \\
\circ \text { Removal of wires at } 4 \text { weeks } \\
\text { - Re-shod with central support shoe at } 8 \text { weeks }\end{array}$ \\
\hline Study design: & Case report \\
\hline Outcome studied: & $\begin{array}{l}\text { No specific outcome studied: } \\
\text { - presence or not of a hoof wall defect } \\
\text { - } \text { soundness } \\
\text { - laceration healing }\end{array}$ \\
\hline $\begin{array}{l}\text { Main findings: } \\
\text { (relevant to PICO question): }\end{array}$ & $\begin{array}{l}\text { - Good apposition of wound edges and medial hoof wall at cast } \\
\text { removal } \\
\text { - At } 2 \text { months after presentation: } \\
\quad \text { Sound } \\
\circ \text { Good healing and apposition of the heel bulb } \\
\text { laceration }\end{array}$ \\
\hline Limitations: & $\begin{array}{l}\text { - } \text { Case report }(\mathrm{N}=1) \\
\text { - Very little detail on how the cast was made and applied } \\
\text { - No long-term follow-up }\end{array}$ \\
\hline
\end{tabular}

\section{Appraisal, application and reflection}

There are very few studies evaluating the efficacy of using distal limb casts when treating heel bulb lacerations compared with bandages alone in horses. Based on the publication from Janicek et al. (2005), casting as opposed to bandaging may reduce the treatment duration of heel bulb lacerations. However, the length of treatment and the success of wound healing are both directly related to the way these wounds are approached, namely if they are treated by primary or secondary closure (Janicek et al., 2005). Since the number of horses in each group (bandaging versus casting) treated with primary closure versus delayed primary or second intention healing was not specified, the conclusion that distal limb casting results in faster healing of heel bulb laceration remains questionable. Janicek et al. (2005) recommended all heel bulb wounds which are minimally contaminated with debris and of short duration following injury ( $<8$ hours) be managed by primary closure and physical support of the site with either a bandage or a cast. In cases of wounds severely contaminated or traumatised, the authors recommended a foot bandage for 7-10 days prior to cast immobilisation. While these recommendations are very logical and allow more frequent monitoring of the wound healing and care, the study results are inconclusive when it comes to favour bandaging or casting to speed up wound healing. On the other hand, Burba et al. (2013), an expert opinion article aimed at veterinary surgeons, stated that heel bulb lacerations were best treated by primary closure when possible and with the use of a foot cast. As this is an opinion piece rather than an original study, no compelling evidence in favour of using foot casts over bandaging was found for these cases.

The potential involvement and treatment of synovial sepsis appears to be an important factor influencing outcome in cases of heel bulb laceration. Janicek et al. (2005) reported that lacerations involving a synovial structure had a significantly poorer outcome than those without. Synovial involvement also influences the approach to the wound. In the study by Janicek et al. (2005), all wounds communicating with synovial structures were left to heal by second intention following surgical management of sepsis. The authors recommended that all lacerations involving synovial structures are considered contaminated and 
recommended delayed primary closure after repeated synovial lavages and natural sealing of the communication between the synovial structure and the wound itself. In the small case series from Booth and Knottenbelt (1999), $50 \%$ of the lacerations were sutured, although the reason for this is not stated in the paper. In a similar publication from Ketzner et al. (2009), 63.6\% of wounds were sutured and the authors found no significant difference in outcome between cases involving or not involving a synovial structure. In a more recent publication on wounds of the lower limb Eggleston (2018), recommends that a wound communicating with a synovial structure be managed with replaceable bandages until it can be confirmed that synovial communication is sealed and the infection resolved. Celeste and Szöke (2005) also recommended bandaging until infectious complications are resolved, after which casting the distal limb in successive periods of 2-3 weeks should be performed. Whilst these recommendations are logical, they constitute expert opinion and we have failed to find corroborating evidence in the literature gathered for this knowledge summary. Prospective studies comparing horses with heel bulb lacerations sutured (or not) in the same fashion, with and without synovial involvement, and divided into two separate groups (bandage versus 'slipper cast') are lacking. If such studies were performed, a standardised treatment plan prior to casting or bandaging would need to be implemented to allow direct comparison of the efficacy of the supportive dressing.

The incidence of cast sores with all types of cast is reported to be anywhere between $45 \%$ to $81 \%$ (Eggleston, 2018). However, if the cast is applied properly and is monitored regularly, the potential for serious complications is significantly reduced and are uncommon (Booth \& Knottenbelt, 1999; and Eggleston, 2018). Janicek et al. (2005) reported that $2 / 15$ horses managed with a cast alone developed pressure necrosis of the skin, which was of limited clinical significance. To further reduce this risk, a 'slipper cast' can be used for casting the foot. It reduces the risk of deep skin erosions if the cast material does not end in the mid-pastern region (Celeste and Szöke, 2005).

Closure of heel bulb lacerations can be challenging due to skin tension and the production of excessive granulation tissue (EGT) is a concern if these wounds are left to heal by second intention (Eggleston, 2018). Booth and Knottenbelt (1999) stated that when properly applied, distal limb casts improve the functional and cosmetic outcome of distal limb injuries. Indeed, since a cast is by definition sturdier than a bandage, is it thought to provide better immobilisation of the distal limb. This led to the clinical impression that casting prevents movement of the foot and wound dehiscence (Janicek et al., 2005; Milner, 2008; and Booth \& Knottenbelt, 1999) as well as decreasing the production of EGT (Smith, 1993). We have failed to find evidence to support this assertion in the available literature and believe this should be considered as expert opinion as well. In the case series from Ketzner et al. (2009), 68.4\% of wounds treated with casting healed with minimal scarring compared to $21.1 \%$ which healed without scarring. While this study includes wounds located to the pastern and hoof area, the number involving heel bulbs is not specified and all horses were treated with a casting, none with bandaging. An in vitro study comparing the immobilisation provided by both types of external coaptation would provide more information.

Casting is also potentially beneficial in cases of heel bulb laceration involving the coronet. When the coronary band is involved in the laceration, reconstructive surgery is paramount to decrease the risk of permanent deformation of the hoof wall and other complications such as hoof cracks and horn spurs (Celeste and Szöke, 2005). Of the 61 horses available at follow-up in the Janicek et al. (2005) study, 18\% developed a hoof wall defect, but the number of horses treated with a foot cast compared to bandaging alone or a combination of the two is not stated. In the study from Ketzner et al. (2009), 10.5\% of all wounds healed with excessive scarring at the coronary band and hoof. As previously mentioned, all horses in that cases series were treated with casting and the number of wounds involving the coronary band/hoof remains unclear. It is therefore not possible to determine if this excessive scarring of the coronet and hoof is the result of a cast complication or of to original injury. The duration of the casting period is also controversial and the ideal timeframe for this immobilisation method is currently unknown. While some authors (Janicek et al., 2005; and O'Neill \& O'Meara, 2010) recommend that casts remain in place for 2-4 weeks in order to allow healthy granulation tissue to cover the wound, the publications identified in this submission each used casting for different periods of time, making it difficult to compare the benefit of shorter versus longer periods in casts. 


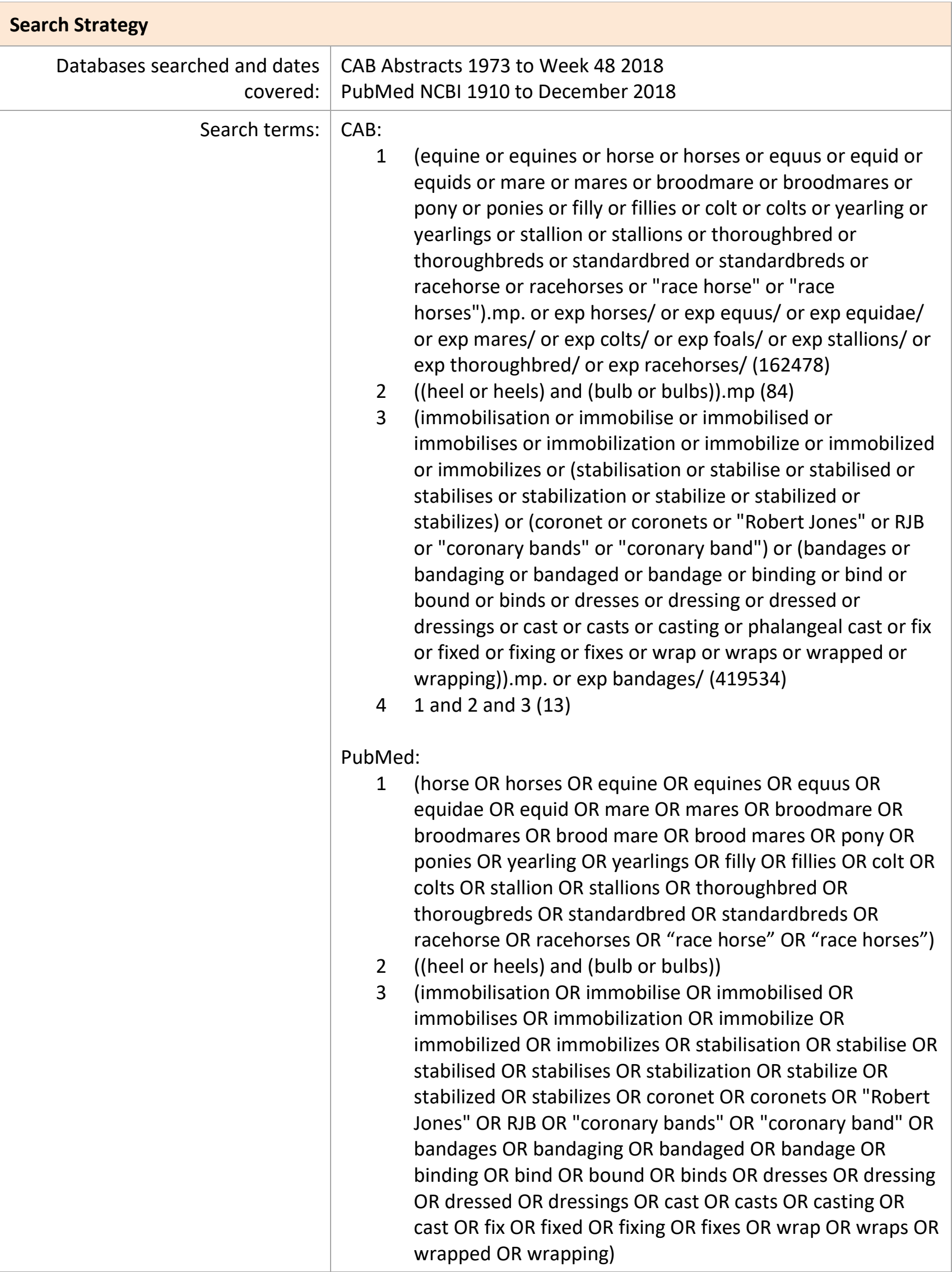


4 (\#1 AND \#2 AND \#3)

Hand search:

Paper identified outside of original search.

Dates searches performed: $7 / 12 / 2018$ and $11 / 12 / 2018$

\section{Exclusion / Inclusion Criteria}

\begin{tabular}{|c|c|}
\hline Exclusion: & $\begin{array}{l}\text { - Articles not relevant to PICO question } \\
\circ \text { Treatment other than casting or bandaging } \\
\circ \text { Species other than equine } \\
\text { - Conference papers/proceedings not published }\end{array}$ \\
\hline Inclusion: & $\begin{array}{l}\text { - Relevant to PICO question } \\
\qquad \text { Foot bandage or hoof cast/slipper cast } \\
\circ \text { Correct wound type (heel bulb/coronet laceration) }\end{array}$ \\
\hline
\end{tabular}

\begin{tabular}{|c|c|c|c|c|c|c|}
\hline \multicolumn{7}{|c|}{ Search Outcome } \\
\hline Database & $\begin{array}{l}\text { Number } \\
\text { of results }\end{array}$ & $\begin{array}{l}\text { Excluded - } \\
\text { duplicates }\end{array}$ & $\begin{array}{c}\text { Excluded - not } \\
\text { published }\end{array}$ & $\begin{array}{l}\text { Excluded - not } \\
\text { relevant to } \\
\text { PICO question }\end{array}$ & $\begin{array}{c}\text { Excluded - } \\
\text { wrong species } \\
\text { treated }\end{array}$ & $\begin{array}{c}\text { Total } \\
\text { relevant } \\
\text { papers }\end{array}$ \\
\hline $\begin{array}{l}\text { CAB Abstracts } \\
\text { on the OVID } \\
\text { interface }\end{array}$ & 13 & 0 & 3 & 6 & 1 & 3 \\
\hline $\begin{array}{l}\text { PubMed } \\
\text { accessed via } \\
\text { the NCBI } \\
\text { website }\end{array}$ & 5 & 4 & 0 & 1 & 0 & 0 \\
\hline Hand search & 1 & 0 & 0 & 0 & 0 & 1 \\
\hline Total relevant & ers & & & & & 4 \\
\hline
\end{tabular}

\section{CONFLICT OF INTEREST}

The authors declare no conflict of interest. 


\section{REFERENCES}

1. Booth, T. M. \& Knottenbelt, D. C. Tutorial Article: Distal limb casts in equine wound management. Equine Veterinary Education; 1999. 11(5):273-280. DOI: https://doi.org/10.1111/i.20423292.1999.tb00962.x

2. Burba, D. J. Traumatic foot injuries in horses: surgical management. Compendium Continuing Education for Veterinarians; 2013. 35(1).

3. Celeste, C. J. \& Szöke, M. O. Management of equine hoof injuries. Veterinary Clinics Equine Practice; 2005. 21:167-190. DOI: https://doi.org/10.1016/i.cveq.2004.11.009

4. Eggleston, R. B. Equine wound management bandages, casts, and external support. Veterinary Clinics Equine; 2018. 34:557-574. DOI: https://doi.org/10.1016/i.cveq.2018.07.010

5. Janicek, J. C., Dabareiner, R. M., Honnas, C. M. \& Crabill, M. A. Heel bulb lacerations in horses: 101 cases (1988-1994). Journal of the American Veterinary Medical Association; 2005. 226(3):418-423. DOI: https://doi.org/10.2460/javma.2005.226.418

6. Ketzner, K. M., Stewart, A. A., Byron, C. R., Stewart, M., Gaughan, E. M., Vanharreveld, P. D. \& Lillich, J. D. Wounds of the pastern and foot region managed with phalangeal casts: 50 casesin 49 horses (19952006). Australian Veterinary Journal; 2009. 87 (9): 363-365. DOI: https://doi.org/10.1111/j.17510813.2009.00471.x

7. Milner, P. Case history - heel bulb laceration in a horse. UK Vet: Companion Animal; 2008. 13(8):4-6. DOI: https://doi.org/10.1111/i.2044-3862.2008.tb00519.x

8. O'Neill, H. \& O'Meara, B. Diagnosis and treatment of penetrating injuries of the hoof in horses. In Practice; 2010. 32:484-490. DOI: https://doi.org/10.1136/inp.c6671

9. Smith, R. W. Bandages and casts. Equine Veterinary Education; 1993. 5:108-112.

DOI: https://doi.org/10.1111/j.2042-3292.1993.tb01012.x.

\section{ACKNOWLEDGEMENT}

RCVS Knowledge was supported in producing this Knowledge Summary by an educational grant from Petplan Charitable Trust. 


\section{EVIIDEFeE

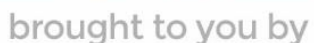 \\ RCVS KNOWLEDGE}

\section{Intellectual Property Rights}

Authors of Knowledge Summaries submitted to RCVS Knowledge for publication will retain copyright in their work, and will be required to grant RCVS Knowledge a non-exclusive license of the rights of copyright in the materials including but not limited to the right to publish, re-

publish, transmit, sell, distribute and otherwise use the materials in all languages and all media throughout the world, and to license or permit others to do so.

\section{Disclaimer}

Knowledge Summaries are a peer-reviewed article type which aims to answer a clinical question based on the best available current evidence. It does not override the responsibility

of the practitioner. Informed decisions should be made by considering such factors as individual clinical expertise and judgement along with patient's circumstances and owners' values. Knowledge Summaries are a resource to help inform and any opinions expressed within the Knowledge Summaries are the author's own and do not necessarily reflect the view of the RCVS Knowledge. Authors are responsible for the accuracy of the content. While the

Editor and Publisher believe that all content herein are in accord with current recommendations and practice at the time of publication, they accept no legal responsibility

for any errors or omissions, and make no warranty, express or implied, with respect to material contained within.

For further information please refer to our Terms of Use.

RCVS Knowledge is the independent charity associated with the Royal College of Veterinary Surgeons (RCVS). Our ambition is to become a global intermediary for evidence based veterinary knowledge by providing access to information

that is of immediate value to practicing veterinary professionals and directly contributes to evidence based clinical decision-making.

https://www.veterinaryevidence.org/

RCVS Knowledge is a registered Charity No. 230886.

Registered as a Company limited by guarantee in England and Wales No. 598443.

Registered Office: Belgravia House, 62-64 Horseferry Road, London SW1P 2AF

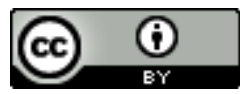

This work is licensed under a Creative Commons Attribution 4.0 International License 